\title{
METHODOLOGICAL APPROACH IN NURSING RESEARCH FOR CONSTRUCTING AND VALIDATING PROTOCOLS
}

\author{
Hellen Lívia Oliveira Catunda ${ }^{1}$ Elizian Braga Rodrigues Bernardo², Camila Teixeira Moreira Vasconcelos ${ }^{3}$, \\ Escolástica Rejane Ferreira Moura ${ }^{4}$, Ana Karina Bezerra Pinheiro ${ }^{5}$, Priscila de Souza Aquino ${ }^{6}$
}

\footnotetext{
${ }^{1}$ M.Sc. in Nursing, Postgraduate Program in Nursing, Universidade Federal do Ceará (UFC). Fortaleza, Ceará, Brazil. E-mail: hellen_enfermagem@yahoo.com.br

${ }^{2}$ M.Sc. in Nursing, Postgraduate Program in Nursing, UFC. Fortaleza, Ceará, Brazil. E-mail: elizbernardo@hotmail.com

${ }^{3}$ Ph.D. in Nursing. Professor, Department of Nursing, UFC. Fortaleza, Ceará, Brazil. E-mail: camilamoreiravasco@gmail.com

${ }^{4}$ Ph.D. in Nursing. Retired Professor, Department of Nursing, UFC. Fortaleza, Ceará, Brazil. E-mail: escolpaz@yahoo.com.br

${ }^{5}$ Ph.D. in Nursing. Professor, Department of Nursing, UFC. Fortaleza, Ceará, Brazil. E-mail: anakarinaufc@hotmail.com

${ }^{6}$ Ph.D. in Nursing. Professor, Department of Nursing, UFC. Fortaleza, Ceará, Brazil. E-mail: priscilapetenf@gmail.com
}

\begin{abstract}
Objective: to highlight the methodological approach used in thesis/dissertations for constructing and validating protocols in the Nursing area. Method: a literature review was performed online at the Library of the Center for Study and Research in Nursing, and at the Thesis Databank of the Coordination for the Improvement of Higher Education Personnel. Eight theses and 16 dissertations were included in the final sample.

Results: it was found that the most common steps in constructing protocols were reviewing the scientific literature and using professionals to assist in this process. In studies related to protocol validation, the presence of groups of specialists/judges on the subject matter ranging from three to 16 in quantity was found, with the majority presenting up to ten judges. Regarding analysis of the validation process, we noticed a higher prevalence of agreement between the judges and the Content Validity Index.

Conclusion: development of this type of technology constitutes a complex and multifaceted area, adapted to researchers' expectations and objectives.

DESCRIPTORS: Protocols. Methods. Academic dissertations. Electronic theses. Validation studies. Nursing.

\section{PERCURSO METODOLÓGICO EM PESQUISAS DE ENFERMAGEM PARA CONSTRUÇÃO E VALIDAÇÃO DE PROTOCOLOS}

\section{RESUMO}

Objetivo: enfocar o percurso metodológico em teses/dissertações para construção e validação de protocolos na área da Enfermagem. Método: utilizou-se como método a revisão da literatura, a qual foi realizada de forma on-line na Biblioteca do Centro de Estudo e Pesquisa em Enfermagem e no Banco de Teses da Coordenação de Aperfeiçoamento de Pessoal de Nível Superior. Foram incluídas oito teses e 16 dissertações na amostra final.

Resultados: verificou-se que as etapas mais comuns na construção de protocolos foram a revisão da literatura científica e a utilização de profissionais para auxiliar nesse processo. Já nos estudos referentes à validação de protocolos, constatou-se a presença de grupos de especialistas/juízes na temática, variando entre três e 16 em quantidade, sendo que a maioria apresentou até dez juízes. Quanto à análise do processo de validação, percebeu-se maior prevalência da concordância entre os juízes e do Índice de Validade de Conteúdo.

Conclusão: o desenvolvimento desse tipo de tecnologia constitui uma arena complexa e multifacetada, adaptada às expectativas e objetivos dos pesquisadores.

DESCRITORES: Protocolos. Métodos. Dissertações acadêmicas. Teses eletrônicas. Estudos de validação. Enfermagem. 


\title{
RECORRIDO METODOLÓGICO EN INVESTIGACIONES DE ENFERMERIA PARA LA CONSTRUCCION Y VALIDACION DE PROTOCOLOS
}

\begin{abstract}
RESUMEN
Objetivo: enfocar el recorrido metodológica en Tesis/Disertación para la construcción y validación de protocolos en el área de enfermería. Método fue utilizado como un método de revisión de la literatura, que se realizó de forma en línea en la Biblioteca del Centro de Estudios e Investigación en Enfermería y en el Banco de Tesis de la Coordinación de Mejora Personal de Nivel Superior. Se incluyeron ocho tesis y 16 disertaciones en la muestra final.

Resultados: se verificó que los pasos más comunes en los protocolos de construcción fueron la revisión de la literatura científica y el uso de los profesionales para ayudar en este proceso. Sin embargo, en los estudios relacionados con los protocolos de validación, se constató la presencia de grupos de expertos/jueces en la temática, que van de tres a 16 en cantidad, y la mayoría presentaron hasta diez jueces. El análisis del proceso de validación, se verificó una mayor prevalencia de concordancia entre los jueces y del índice de validez de contenido. Conclusión: el desarrollo de estas tecnologías se constituye en un escenario complejo y multifacético, adaptado a las expectativas y objetivos de los investigadores.
\end{abstract}

DESCRIPTORES: Protocolos. Métodos. Disertaciones académicas. Tesis electrónicas. Estudios de validación. Enfermería.

\section{INTRODUCTION}

Protocols are recommendations structured in a systematic way, with the purpose of guiding health professionals and / or users' decisions regarding adequate care in specific clinical circumstances. These recommendations are based on scientific evidence, on the technological and economic evaluation of health services and their quality assurance. ${ }^{1}$

However, in relation to the development of protocols, it is difficult to find a single approach with a valid and comprehensive approach, since there is a great variety of methodologies implemented. ${ }^{1}$ This is due to the fact that each method, besides having their own characteristics, suits the specificities of the problem, as well as the study objectives and purposes. Therefore, the researcher needs to have a concise definition of the research problem as the most important step in the scientific research process in order to select the most appropriate method. ${ }^{2}$

The combination of several methodologies in certain types of studies may, however, contribute to a lack of rigor. It is recommended that methodological standards with proven efficacy are followed, ${ }^{3}$ which is a challenge. Thus, since there is no consensus on the most correct methodology, studying recommendations for protocol development is justified since there is a need to clarify this process. ${ }^{4}$

Knowledge production disseminated by dissertations and theses represents the development of scientific research and processes of knowledge production by researchers. In this context, Nursing has been dedicating itself to constructing its own knowledge, and scientific production in this area has intensified over the years. ${ }^{5}$

In this context, analysis of the production of theses and dissertations developed by nurses leads to the desire to reflect on Nursing practice and knowledge construction and relating it to the various Post-Graduation Programs. We understand that from this reflection, it is possible to understand the directions of Nursing research and their interfaces for health promotion.

Therefore, the objective of the present study is to focus on the methodological approach used by Brazilian researchers in theses and dissertations in the area of Nursing for constructing and validating protocols based on a literature review. Our objective through this approach is to verify the methods and references most commonly used in the literature, understanding that disseminating these types of scientific production are of fundamental importance so that future researchers can choose the methodological approach that best meets their objectives.

\section{METHOD}

In order to undertake this study, we used the literature review research method, with the purpose of gathering and synthesizing research results on a specific subject to deepen the understanding of the investigated subject. ${ }^{6}$

In order to guide this study, the following question was posed: What is the methodological approach used by Brazilian researchers in theses / dissertations in the Nursing area for constructing and/or validating protocols?

The following steps were taken to carry out this literature review: a) defining the theme and formulating the guiding question; $b$ ) establishing the criteria for selecting the publications; $c$ ) defining the information to be extracted from the selected studies and their categorization; d) analyzing the studies; e) interpreting the findings; and f) disseminating synthesized and evaluated knowledge. ${ }^{6}$ 
The inclusion criteria adopted for selecting theses and dissertations were as follows: Encompassing protocol development and/or validation; being available electronically; being published in full. Studies that did not meet these criteria were excluded.

A search for theses and dissertations was performed in the Library of the Center for Study and Research in Nursing (CEPEn), created on July 17,1971 , to disseminate research in this knowledge area. This collection can be found in the Library Automation System (SIAB), on the Brazilian Nursing Association's (ABEn) website. The Thesis Databank of the Coordination for the Improvement of Higher Education Personnel (CAPES) was also consulted, initially created in July 2002 with the aim of facilitating access to theses and dissertations defended in Postgraduate Programs across the country.
This search was carried out online in April 2015 on two consecutive days, using the keyword "Protocolo". The CAPES Theses Databank is a databank that covers all areas of knowledge, thus we decided to restrict the search to the "Nursing" area in order to achieve the purpose of the review. This investigation resulted in 140 theses/dissertation hits in the CAPES Theses Databank, and 62 in the CEPEn Library.

Next, titles and abstracts of each of these scientific productions were read. From these readings, theses and dissertations that did not include protocol construction and/or validation were excluded, as well as those duplicated in the databases researched in this study. Next, the selected dissertations and theses were searched in-full, and those unavailable were excluded from the initial sample; therefore, a total of 24 theses/dissertations remained, as shown in figure 1.

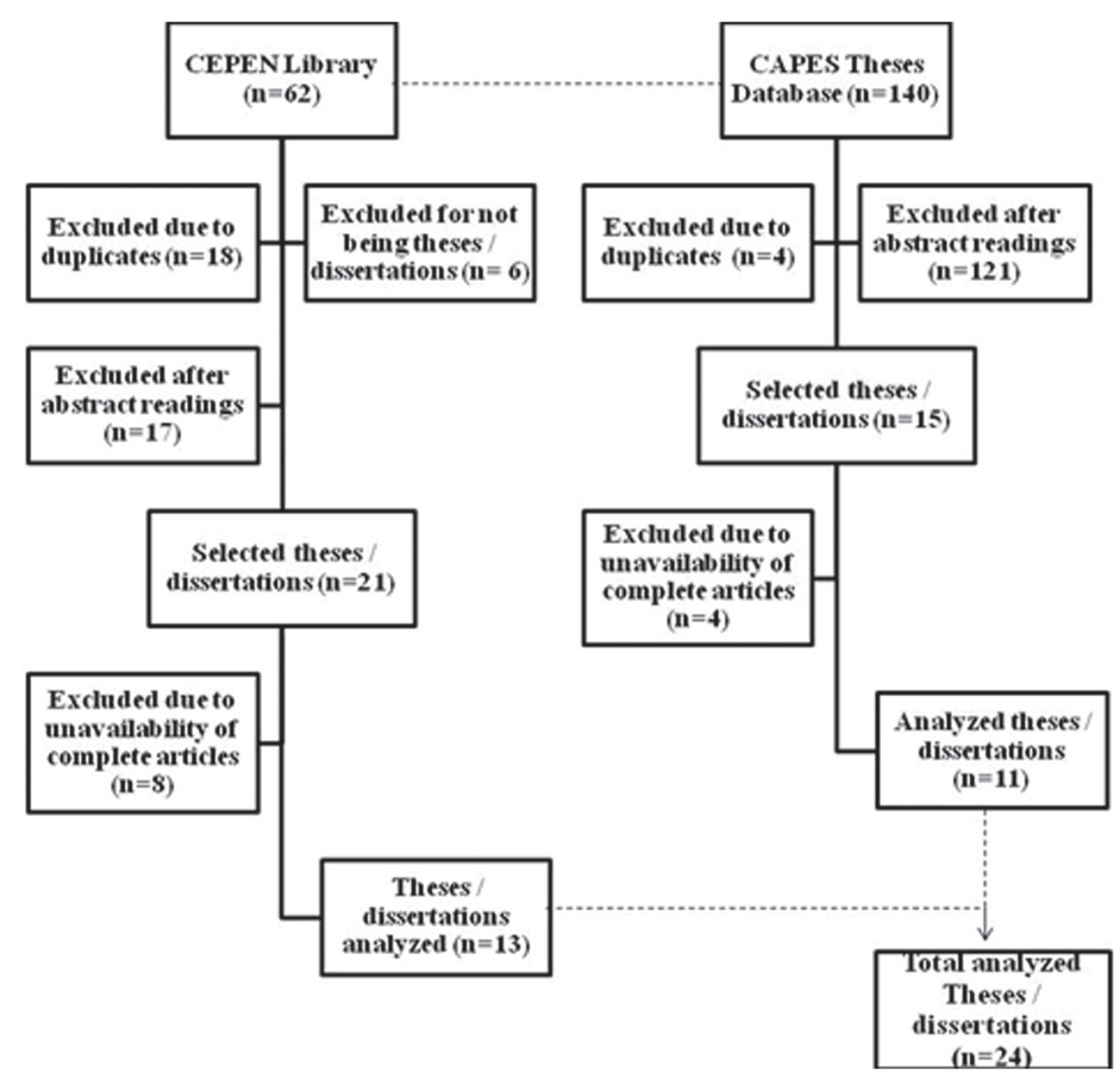

Figure 1 - Flowchart of the theses/dissertations' selection process included in the literature review. Fortaleza-CE, Brazil, 2015 
After selection, the theses and dissertations were read in full, and the data for analysis and synthesis were extracted and organized using a collection instrument adapted from Ursi, ${ }^{7}$ which includes the following aspects: theses/dissertations' identification data (title, author's name, year of publication, university, type of post-graduation and specification of the Postgraduate Program); study type; objective(s); protocol theme; and presence of methodological reference and protocol construction/validation.

This instrument allowed cataloging of theses and dissertations, and registration of the required information. The results are presented descriptively and in a chart.

\section{RESULTS}

Regarding the publication year of the included theses/dissertations, a variation was observed between 2002 and 2014, where 2012 and 2013 were the most prevalent years with 13 studies, equivalent to $54.1 \%$.

We also found that the universities with the most publications on the object of the pres- ent study were the Federal University of Santa Catarina (UFSC) - seven studies (29.2\%); the Federal University of Ceará (UFC) - six studies (25\%); and the University of São Paulo (USP) three studies $(12.5 \%)$.

Regarding the types of selected studies, eight were theses $(33.3 \%)$ and 16 were dissertations $(66.7 \%)$, the majority were produced in academic postgraduate studies in Nursing - five theses (20.8\%) and 10 dissertations (41.7\%); while a minority focused on other areas - four (16.7\%). Five dissertations (20.8\%) were also found within the professional master's degree in Nursing Care Management.

In analyzing the postgraduation programs, we can highlight that most of the studies - 21 $(87.5 \%)$ - were inserted in Nursing; while a small part were included in the postgraduate program in Fundamental Nursing and in Nursing Management - three $(12.5 \%)$.

Table 1 shows the characteristics of theses/ dissertations, their authorship, protocol theme, the existence of (or lack thereof) methodological reference and construction/validation.

Table 1 - Characteristics of the theses/dissertations in the CEPEn Library and the CAPES Theses Databank, according to author, protocol theme, methodological reference, construction and validation. Fortaleza-CE, Brazil, 2015

\begin{tabular}{|c|c|c|c|c|}
\hline Author & Protocol theme & Methodological reference & Construction & Validation \\
\hline $\begin{array}{l}\text { Moraes GLA }{ }^{8} \\
\text { (T1) }\end{array}$ & Pressure ulcer prevention & No & Yes & Yes \\
\hline $\begin{array}{l}\text { Franco } \mathrm{BAS}^{9} \\
\text { (T2) }\end{array}$ & $\begin{array}{l}\text { Physical exercises based } \\
\text { on the Pilates method and } \\
\text { conventional stretching and } \\
\text { strengthening physical ex- } \\
\text { ercises }\end{array}$ & No & Yes & No \\
\hline $\begin{array}{l}\text { Rogenski } \\
\mathrm{NMB}^{10} \\
\text { (T3) }\end{array}$ & Pressure ulcer prevention & No & Yes & No \\
\hline $\begin{array}{l}\text { Aquino DR }{ }^{11} \\
\text { (D4) }\end{array}$ & Nursing interventions & Care-converging research & Yes & No \\
\hline $\begin{array}{l}\text { Campos FA } \\
\text { (D5) }\end{array}$ & Enteral nutrition therapy & $\begin{array}{l}\text { Stetler; } \\
\text { Werneck et al. }\end{array}$ & Yes & Yes \\
\hline $\begin{array}{l}\text { Vasconcelos } \\
\text { JMB }^{13} \\
\text { (T6) }\end{array}$ & Pressure ulcer prevention & $\begin{array}{l}\text { Rogers; } \\
\text { Model for implementation } \\
\text { of guidelines for clini- } \\
\text { cal practice Registered } \\
\text { Nurses' Association of } \\
\text { Ontario }\end{array}$ & Yes & No \\
\hline $\begin{array}{l}\text { Marcon L }{ }^{14} \\
\text { (D7) }\end{array}$ & $\begin{array}{l}\text { Nursing care for patients } \\
\text { with severe head trauma }\end{array}$ & $\begin{array}{l}\text { Formarier and Jovic; } \\
\text { care-converging Research }\end{array}$ & Yes & No \\
\hline
\end{tabular}




\begin{tabular}{|c|c|c|c|c|}
\hline Author & Protocol theme & Methodological reference & Construction & Validation \\
\hline $\begin{array}{l}\text { Lima GOP } \\
\text { (D8) }\end{array}$ & $\begin{array}{l}\text { Investigation of acute respi- } \\
\text { ratory disorders }\end{array}$ & No & Yes & Yes \\
\hline $\begin{array}{l}\text { Braz } \mathrm{MR}^{16} \\
\text { (T9) }\end{array}$ & $\begin{array}{l}\text { T-tube and synchronized } \\
\text { intermittent mandatory } \\
\text { ventilation in ventilatory } \\
\text { weaning }\end{array}$ & No & Yes & No \\
\hline $\begin{array}{l}\text { Lima } \mathrm{FET}^{17} \\
\text { (T10) }\end{array}$ & $\begin{array}{l}\text { Nursing consultations to } \\
\text { people undergoing coronary } \\
\text { artery bypass grafting }\end{array}$ & No & Yes & No \\
\hline $\begin{array}{l}\text { Fernandes } \\
\text { RTP18 }^{18} \\
\text { (D11) }\end{array}$ & $\begin{array}{l}\text { Continuous nursing care for } \\
\text { polytrauma patients in the } \\
\text { emergency room }\end{array}$ & No & Yes & No \\
\hline $\begin{array}{l}\text { Schweitzer } \mathrm{G}^{19} \\
\text { (D12) }\end{array}$ & $\begin{array}{l}\text { Assistance to adult patients } \\
\text { victim of trauma in the aero- } \\
\text { space environment }\end{array}$ & Care-converging research & Yes & No \\
\hline $\begin{array}{l}\text { Felix LG Lo } \\
\text { (D13) }\end{array}$ & $\begin{array}{l}\text { Nursing care guidance for } \\
\text { patients undergoing bariat- } \\
\text { ric surgery }\end{array}$ & No & Yes & No \\
\hline $\begin{array}{l}\text { Rosini } \mathrm{I}^{21} \\
\text { (D14) }\end{array}$ & $\begin{array}{l}\text { Care of clients/patients sub- } \\
\text { mitted to breast and thyroid } \\
\text { fine-needle aspiration }\end{array}$ & Care-converging research & Yes & Yes \\
\hline $\begin{array}{l}\text { Selhorst ISB } 22 \\
\text { (D15) }\end{array}$ & $\begin{array}{l}\text { User embracement of pa- } \\
\text { tients undergoing upper } \\
\text { endoscopy and their com- } \\
\text { panions }\end{array}$ & No & Yes & Yes \\
\hline $\begin{array}{l}\text { Veras JEGLF }{ }^{23} \\
\text { (D16) }\end{array}$ & $\begin{array}{l}\text { Abbreviated user embrace- } \\
\text { ment protocol guide with } \\
\text { pediatric risk classification }\end{array}$ & No & Yes & Yes \\
\hline $\begin{array}{l}\text { Magalhães FJ' } \\
\text { (D17) }\end{array}$ & $\begin{array}{l}\text { User embracement with pe- } \\
\text { diatric risk classification }\end{array}$ & No & No & Yes \\
\hline $\begin{array}{l}\text { Bessa } \mathrm{MPE}^{25} \\
\text { (T18) }\end{array}$ & $\begin{array}{l}\text { Care for elderly at risk of } \\
\text { frailty }\end{array}$ & Ribeiro & Yes & Yes \\
\hline $\begin{array}{l}\text { Cordeiro RA }{ }^{26} \\
\text { (D19) }\end{array}$ & $\begin{array}{l}\text { Care based on non-phar- } \\
\text { macological methods for } \\
\text { discomfort and pain in new- } \\
\text { borns }\end{array}$ & Care-converging research & Yes & No \\
\hline $\begin{array}{l}\text { Veronez } \mathrm{M}^{27} \\
\text { (D20) }\end{array}$ & Discharge in neonatology & Care-converging research & Yes & No \\
\hline $\begin{array}{l}\text { Vieira } \mathrm{RHG}^{28} \\
\text { (D21) }\end{array}$ & $\begin{array}{l}\text { Adherence of nursing staff } \\
\text { to influenza vaccination }\end{array}$ & No & Yes & No \\
\hline $\begin{array}{l}\text { Azzolin } \mathrm{KO}^{29} \\
\text { (T22) }\end{array}$ & Care of heart failure patients & No & Yes & Yes \\
\hline $\begin{array}{l}\text { Nienkotter } \\
\text { SMV } \\
\text { (D23) }\end{array}$ & $\begin{array}{l}\text { Welcoming the companion } \\
\text { of adult patients in critical } \\
\text { health condition }\end{array}$ & Care-converging research & Yes & No \\
\hline $\begin{array}{l}\text { Santos SCVO } \\
\text { (D24) }\end{array}$ & Enteral probe insertion & No & Yes & No \\
\hline
\end{tabular}

T: Theses; D: Dissertation.

The following information was verified regarding the methodological reference: 14 (58.3\%) theses/dissertations did not include the framework used for protocol construction and validation; six $(25 \%)$ resorted to Care-converging research (CCR); one $(4.2 \%)$ used the ideas of Formarier and Jovic, ${ }^{32}$ 
associating them to CCR; one (4.2\%) adopted Rogers $^{33}$ and the Model for Implementing Guidelines for Clinical Practice from the Registered Nurses' Association of Ontario (RNAO) ${ }^{34}$ one (4.2\%) opted for the ideas of Stetler ${ }^{35}$ and Werneck et al.; ${ }^{36}$ and one $(4.2 \%)$ chose Ribeiro ${ }^{37}$ as a reference.

Below are the methodological approaches used in the thesis/ dissertations selected for the constructing and/or validating protocols. For organizational purposes, the findings were divided according to their objectives into: protocol construction and validation studies $(n=8)$; protocol construction studies $(\mathrm{n}=15)$; and protocol validation studies $(\mathrm{n}=1)$.

From synthesizing the knowledge of the methodologies approached in the dissertations and theses that constructed and validated protocols, the following was observed in the construction phase: the majority, six (75\%), guaranteed scientific literature revision as an essential step; more than half, five (62.5\%), used the professional as an important member for this phase; two $(25 \%)$ considered the researcher's experience/background; and two (25\%) resorted to participation of target patients in the protocol. In the validation phase, we noticed that the number of judges varied between three and 16, with up to 10 judges in five (62.5\%) theses/dissertations, and over 10 judges in three (37.5\%). Regarding analysis tests for the validation process, we found that half, four (50\%), used judges agreement; three (37.5\%) used Content Validity Index (CVI); two (25\%) made use of data categorization and interpretation; one (12.5\%) used the binomial test; and one (12.5\%) adopted the Cronbach alpha coefficient.

Regarding protocol construction studies, we found that seven $(46.7 \%)$ of the theses and dissertations used professionals to assist in construction; six (40\%) adopted reality observation; six (40\%) chose to review scientific literature; four $(26.7 \%)$ chose to use target patients; two (13.3\%) used the researcher's experience/ background; and one (6.7\%) did not mention it.

In the only protocol validation study, we found that content validation and appearance was based on a specific form, and nine judges or experts on the subject were included in the trial at that stage, presenting a score equal to or greater than five according to their own criteria. CVI was used to analyze the validation process.

\section{DISCUSSION}

In recent years, the Nursing postgraduate programs in Brazil have been growing significantly and acquiring a prominent position in the area of higher education of the country. Thus, these programs have constituted spaces for training new researchers, producing new knowledge and new technologies. The availability of theses and dissertations in electronic databases has made the great leap of academic production in Brazil evident. ${ }^{38}$

UFSC and UFC were the universities that most stood out with their publications on constructing and/or validating protocols. Graduate programs of these universities have recognition of excellence at an international level. The UFSC Program was created in 1976 with the Master's course, and started to offer the doctorate course in 1993. On the other hand, the UFC had its Program created in 1993 with the Master's course, expanding it in 1998 with the Doctorate (Ph.D.) course. These programs significantly contribute to academic training of health professionals, especially nurses, and to advances in research. ${ }^{39-40}$

From the data collected by the present study, it was possible to identify theses and dissertations carried out in the Nursing area between 2002 and 2014 that constructed and/or validated protocols. We found a greater incidence of this topic starting from 2012, which reflects an increasing use of this methodology in nursing research and demonstrates acceptance and recognition of the importance of this approach. However, it is important to discuss how such a proposal has been presented and developed in order to clarify its methodological approaches.

Among the methodological references observed, we noticed that CCR was the most used. Ideas from other authors ${ }^{32-33,35-37}$ and a model of guideline implementation for clinical practice ${ }^{34}$ were also used.

Implementation of CCR requires that researchers are aware of the objective concerning changes in care, in addition to developing the research. This is because adopting changes in care may lead to a methodological approach for elaborating care models, such as protocols with inductive-deductive logic, promoting renewal or innovation of care practice. ${ }^{41}$

Adherence to CCR as a methodological reference has become a research approach in Brazilian postgraduate courses, especially in the Nursing area. This has had repercussions on scientific production, especially in protocol development. ${ }^{38}$

In addition to CCR, Formarier and Jovic ${ }^{32}$ were also cited as a reference for protocol development. This framework describes the methodology of care protocol construction based on the theoreticalconstructivist framework. ${ }^{32}$ 
In Nursing, the diffusion of innovations theory created by Rogers ${ }^{33}$ focuses on the process of using research results to improve care and incorporate other evidence such as guidelines for clinical practice based on the opinion of experts, especially in areas where scientific studies are scarce or do not indicate the best solution for dealing with a problem. ${ }^{42}$

$\mathrm{RNAO}^{34}$ is related to the Evidence-Based Practice (EBP) movement, proposing a model for implementing guidelines for clinical practice. This model seeks to assist health services in maximizing the potential of guidelines by implementing them in a systematic and planned manner. To do so, this model has six essential components: identifying the guidelines to be used in clinical practice; identifying participants or collaborators; evaluating their interests and engagement in the implementation proposal; assessing environmental conditions; strategies for implementation; evaluating guideline implementation; and identifying the resources needed to achieve the objectives. ${ }^{34}$

The Stetler ${ }^{35}$ model also proposes completing six phases: establishing literature review purposes; critically analyzing the studies; comparative evaluation; decision and implementation of the results in the care; constructing protocols with the purpose of equipping nurses for care, management and training activities; and, finally, validating the designed instrument. The purpose of this model is promoting the practice in which nurses seek and implement scientific knowledge into their care. ${ }^{35}$

Another framework cited in the literature review in the present study was Werneck et al. ${ }^{36} \mathrm{Ac}-$ cording to these authors, protocols can be designed in text format, observing essential aspects such as: introduction, justification, objectives, constraints, determinants, magnitude, transcendence, vulnerability, effects, activities, and accountability. For these authors, the protocols can also be constructed in the form of tables, based on a sequence description of the steps to be followed with appropriate recommendations for the professionals. Another form of graphical representation is the use of flowcharts with algorithms, which can qualify the representation and facilitate professionals' understanding. ${ }^{36}$

Ribeiro $^{37}$ also points out steps for developing protocols and indicates options for instruments that guarantee an evaluation of the quality of such protocols. In summary, eight important points must be observed to do so: defining topics or issues; carrying out a systematic review; preparing recommendations for various scenarios; scheduling a guideline/protocol update; a review by experts, organizations and professionals; planning dissemination of the guideline/protocol; approval of the text; and implementation. Among the most reliable, tested and recommended instruments for evaluating protocols are the 'Appraisal of Guidelines for Research and Evaluation' (AGREE), the 'checklist' designed by the World Health Organization (WHO), and another prepared by the Agency for Healthcare Research and Quality (AHRQ)/National Guideline Clearinghouse (NGC). ${ }^{37}$

It becomes clear that these references contain variations in the way protocols should be developed. However, this development should not hinder their quality, and in order to avoid this, the protocol should always seek to meet the needs of those to whom it is intended so that health care can be more effective.

On the other hand, the present study found that despite variations in the methods, there are common steps such as: revision of scientific literature; the use of professionals as an important member for protocol elaboration; the researcher's experience/background; the participation of target patients of the protocol to assist in its elaboration; and validation by judges specialized in the protocol's theme.

Integration of the best available evidence in the literature and professional's clinical experience, patient preferences and resources available at the institution are characteristics of Evidence Based Practice (EBP), which focuses on solving problems, thereby seeking to improve care and seeking to identify and promote efficient practices for patient care. ${ }^{43}$

Seeking better scientific evidence that justifies proposed actions is essential for protocol development. Professional's experience and competence through which the decision-making process is improved should also be considered. Moreover, in order to ensure that the protocol is accepted and useful, service users cannot be excluded, which may occur during the elaboration phase and during validation by the professionals who will use it. ${ }^{36,44}$

A protocol only becomes effective when it covers the specific needs of the public to which it is intended and when it corresponds to health professionals' expectations. An evaluation by the professionals who will use the protocol reflect the need for a consistent health technology, effective with the reality rather than just a generalist instrument. ${ }^{45}$

Another point discussed is the professional qualification and the number of judges during a validation of a technology. The literature presents controversies on this issue; however, the character- 
istics of the instrument, training, and qualification, whether being related to clinical experience, the research or knowledge production in the subject and the knowledge about the conceptual and methodological structure of the construction process of technologies, in addition to the availability of the necessary professionals, must be taken into account. ${ }^{46}$

Regarding the required number of judges for content validation, the ideal number for this process should be between three and ten. ${ }^{47}$ Six judges are sufficient to carry out such an examination. ${ }^{48}$ AGREE ${ }^{49}$ recommends that each guideline be evaluated by at least two judges, and preferably by four evaluators in order to increase the assessment's reliability.

Regarding the validation process analysis, we found a higher prevalence of agreement between judges and adoption of CVI. Publications have presented different ways of quantifying the degree of agreement between judges during the process of assessing an instrument's validity.

Among these, we can highlight the interobserver agreement percentage, which is useful and easily calculated, where a 90\% agreement between the judges can be considered acceptable, however this percentage may vary. CVI is a widely used method in the health area that allows for initially analyzing each item individually, and then a Likert scale to analyze the instrument as a whole should also be considered. According to this method, the acceptable agreement rate between the judges can vary between 0.78 and 1.00 , depending on the number of participants. ${ }^{46}$

In summary, the present review is useful for an overview of the most used construction and validation methods in nursing research in Brazil. However, as a limitation we can point out restricting the search to only the nursing context, as it is also relevant to know the methods employed by other areas in this type of production. Another limitation was the unavailability of complete dissertations and theses which answered the guiding question, restricting access to only the abstract which reduces the evidence of data produced in studies with this scope.

We hope that the elucidated results can serve as subsidies to direct studies on construction and validation of clinical protocols, not only in the Nursing area, but also in several other health areas.

\section{CONCLUSION}

After analyzing the dissertations/theses, we found that different methods are chosen for constructing and validating clinical guidelines or protocols, which means that there is no uniformity.
This is due to the use of a wide variety of conducts, which confirms the absence of a standard methodological approach.

However, we found that the most common steps among all the analyzed studies for constructing protocols were a review of scientific literature and the use of professionals to assist in this process - $12(52.2 \%)$ for each one. Next, we verified prevalence of reality observation and use of target patients - six $(26.1 \%)$ in each one; researcher's experience/ background - four (17.4\%). One of the studies, $4.3 \%$, did not include it.

Regarding validation studies, the presence of groups of experts/judges was verified. The number of individuals in these groups varied between three and 16 , where six groups $(66.7 \%)$ had up to 10 judges, and three (33.3\%) had more than 10.

Concerning the validation process analysis, we found a higher prevalence of agreement between judges and CVI adoption - four (44.4\%) each. Next, we observed the presence of categorization and interpretation of data - two $(22.2 \%)$, binomial testing and Cronbach's alpha coefficient - one (11.1\%) each.

Therefore, it should be noted that most of the studies present their own methodology for elaborating guidelines, and we conclude that development of this type of technology constitutes a complex and multifaceted area adapted to researchers' expectations and their objectives.

\section{Acknowledgement}

The authors thank National Counsel of Technological and Scientific Development (CNPq), Universal 14/2014, process number 459445/2014-6, for their financial support.

\section{REFERENCES}

1. Rosenfeld RM, Shiffman RN, Robertson P. Clinical Practice Guideline Development Manual, third edition: a quality-driven approach for translating evidence into action. Otolaryngol. Head Neck Surg. 2013 Jan; 148(1):1-55.

2. Hulley SB, Cummings SR, Browner WS, Grady DG, Newman TB. Delineamento de pesquisa clínica. Porto Alegre (RS): Artmed, 2015.

3. Bernardo EBR, Catunda HLO, Oliveira MF, Lessa PRA, Ribeiro SG, Pinheiro AKB. Methodological approach to translation and adaptation of scales in the area of sexual and reproductive health: an integrative review. Rev Bras Enferm. 2013 Jul-Ago; 66(4):592-8.

4. Michie S, Berentson-Shaw J, Pilling S, Feder G, Dieppe $P$, Raine $R$, et al. Turning evidence into 
recommendations: protocol of a study guideline development groups. Implement. Sci. 2007 Sep; 2(29):1-5.

5. Baggio MA, Rodrigues MA, Erdmann AL, Figueiredo MCAB, Vieira MMS. Production of nursing thesis and dissertations in Portugal, 2000-2010: a bibliometric study. Texto Contexto Enferm [Internet]. 2014 Abr-Jun [cited 2016 Oct 31]; 23(2):250-60. Available from: http:/ / www.scielo.br/scielo.php?script=sci_ arttext\&pid=S0104-07072014000200250

6. Mendes KDS, Silveira RCCP, Galvão CM. Integrative literature review: a research method to incorporate evidence in health care and nursing. Texto Contexto Enferm. 2008 Out-Dez; 17(4):758-64.

7. Ursi ES. Prevenção de lesões de pele no perioperatório: revisão integrativa da literatura [dissertação]. Ribeirão Preto (SP): Universidade de São Paulo. Escola de Enfermagem; 2005.

8. Moraes GLA. Adaptação e validação de protocolo para prevenção de úlcera por pressão em idosos assistidos no domicílio [tese]. Fortaleza (CE): Universidade Federal do Ceará. Departamento de Enfermagem; 2011.

9. Franco BAS. Avaliação da eficácia de um protocolo de exercícios físicos baseado no método Pilates nas variáveis dor lombar, flexibilidade e força muscular em profissionais de enfermagem com lombalgia crônica idiopática [tese]. Ribeirão Preto (SP): Universidade de São Paulo, Escola de Enfermagem; 2010.

10. Rogenski NMB. Avaliação da implementação de um protocolo de prevenção de úlceras por pressão [tese]. Ribeirão Preto (SP): Universidade de São Paulo. Escola de Enfermagem; 2011.

11. Aquino DR. Construção e implantação da prescrição de enfermagem informatizada em uma UTI [dissertação]. Rio Grande (RS): Fundação Universidade Federal do Rio Grande, Programa de Pós-graduação em Enfermagem; 2004.

12. Campos FA. Construção e validação de protocolo de terapia de nutrição enteral [dissertação]. Fortaleza (CE): Universidade Federal do Ceará, Departamento de Enfermagem; 2013.

13. Vasconcelos JMB. Construção, utilização e avaliação dos efeitos de protocolo de prevenção de úlceras por pressão em unidade de terapia intensiva [tese]. Ribeirão Preto (SP): Universidade de São Paulo. Escola de Enfermagem; 2014.

14. Marcon L. Uma construção coletiva: protocolo de cuidados de enfermagem dos pacientes com traumatismo crânio-encefálico severo internados em unidade de terapia intensiva [dissertação]. Florianópolis (SC): Universidade Federal de Santa Catarina, Centro de Ciências da Saúde; 2002.

15. Lima GOP. Cuidando do cliente com distúrbio respiratório agudo: proposta de um protocolo assistencial para tomar decisões em enfermagem [dissertação]. Rio de Janeiro (RJ): Universidade
Federal do Estado do Rio de Janeiro, Escola de Enfermagem Alfredo Pinto; 2006.

16. Braz MR. Desmame ventilatório no pós-operatório imediato de cirurgia cardíaca: implantação de um protocolo por enfermeiras [tese]. Rio de Janeiro (RJ): Universidade Federal do Rio de Janeiro. Escola de Enfermagem Anna Nery; 2008.

17. Lima FET. Protocolo de consultas de enfermagem ao paciente após a revascularização do miocárdio: avaliação da eficácia [tese]. Fortaleza (CE): Universidade Federal do Ceará, Departamento de Enfermagem; 2007.

18. Fernandes RTP. Protocolo de cuidados contínuos de enfermagem a politraumatizados na sala de emergência [dissertação]. Rio de Janeiro (RJ): Universidade Federal do Rio de Janeiro, Escola de Enfermagem Anna Nery; 2008.

19. Schweitzer G. Protocolo de cuidados de enfermagem no ambiente aeroespacial a adultos vítimas de trauma: uma pesquisa convergente-assistencial [dissertação]. Florianópolis (SC): Universidade Federal de Santa Catarina, Centro de Ciências da Saúde; 2010.

20. Felix LG. Protocolo de orientação para o autocuidado de pacientes submetidos à cirurgia bariátrica: atuação do enfermeiro [dissertação]. João Pessoa (PB): Universidade Federal da Paraíba, Centro de Ciências da Saúde; 2009.

21. Rosini I. Protocolo de cuidado a clientes submetidos à punção aspirativa por agulha fina [dissertação]. Florianópolis (SC): Universidade Federal de Santa Catarina, Centro de Ciências da Saúde; 2011.

22. Selhorst ISB. Protocolo de acolhimento para usuários submetidos à endoscopia digestiva alta e seus acompanhantes [dissertação]. Florianópolis (SC): Universidade Federal de Santa Catarina, Centro de Ciências da Saúde; 2011.

23. Veras JEGLF. Construção e validação de um guia abreviado do protocolo de acolhimento com classificação de risco em pediatria [dissertação]. Fortaleza (CE): Universidade Federal do Ceará, Departamento de Enfermagem; 2011.

24. Magalhães FJ. Validação do protocolo de acolhimento com classificação de risco em pediatria [dissertação]. Fortaleza (CE): Universidade Federal do Ceará, Departamento de Enfermagem; 2012.

25. Bessa MEP. Elaboração e validação de conteúdo do protocolo de intervenções de enfermagem para idosos com risco de apresentar fragilidade [tese]. Fortaleza (CE): Universidade Federal do Ceará, Departamento de Enfermagem; 2012.

26. Cordeiro RA. Reflexão da equipe de enfermagem sobre o desconforto e a dor do recém-nascido: uma proposta de protocolo de cuidado baseado nos métodos nãofarmacológicos [dissertação]. Florianópolis (SC): Universidade Federal de Santa Catarina, Centro de Ciências da Saúde; 2012.

27. Veronez M. Protocolo de alta em neonatologia: 
importância da ação educativa no contexto do cuidado ao bebê pré-termo [dissertação]. Maringá (PR): Universidade Estadual de Maringá, Departamento de Enfermagem; 2012.

28. Vieira RHG. Situação vacinal contra a influenza dos profissionais de enfermagem em um hospital de ensino: diagnóstico e intervenções [dissertação]. Florianópolis (SC): Universidade Federal de Santa Catarina, Centro de Ciências da Saúde; 2011.

29. Azzolin KO. Efetividade da implementação das intervenções de enfermagem nos resultados esperados de pacientes com insuficiência cardíaca em cuidado domiciliar [tese]. Porto Alegre(RS): UniversidadeFederal do Rio Grande do Sul, Escola de Enfermagem; 2011.

30. Nienkotter SMV. Acolhimento aos acompanhantes de pessoas adultas em situação crítica de saúde em serviço de emergência [dissertação]. Florianópolis (SC): Universidade Federal de Santa Catarina, Centro de Ciências da Saúde; 2011.

31. Santos SCVO. Definição de uma medida para a introdução de sonda enteral em posição gástrica em adultos: fatores limitantes [dissertação]. Campinas (SP): Universidade Estadual de Campinas, Faculdade de Ciências Médicas; 2012.

32. Formarier M, Jovic L. Hors. Serie recherche en soins infimers. Special Methodolge. RSI. 1993 Mar; 32:127-36.

33. Rogers, E. M. Diffusion of innovations. $5^{\mathrm{a}}$ ed. New York (US): Free Pass; 2003.

34. Registered Nurses Association of Ontario. Toolkit: implementation of clinical practice guidelines. Toronto (CA): Registered Nurses Association of Ontario; 2002.

35. Stetler BC. Utilization-focused integrative reviews in a nursing service. Appls Nurs Res. 1998 Nov; 11(4):195-206.

36. Werneck MAF, Faria HP, Campos KFC. Protocolo de cuidado à saúde e organização do serviço. Belo Horizonte (MG): Coopmed; 2009.

37. Ribeiro RC. Clinical guidelines: how to evaluate its quality? Rev Soc Bras Clín Méd. 2010 Jul-Ago; 8(4):350-5.

38. Reibnitz KS, Prado ML, Lima MM, Kloh D. Convergentcare research: bibliometric study of dissertations and theses. Texto Contexto Enferm [Internet]. 2012 Jul-Set [cited 2016 Oct 31]; 21(3):702-7. Available from: http:/ / www.scielo.br/scielo. php?script=sci_ arttext\&pid=S0104-07072012000300027

39. Backes VMS, Brüggemann OM. The post graduate program in nursing of the federal university of Santa Catarina: 40 years contributing to the excellence in education. Texto Contexto Enferm [Internet]. 2016 Jul [cited 2016 Oct 31]; 25(2):editorial. Available from: http://www.scielo.br/scielo.php?script=sci arttext\&pid=S0104-07072016000200201

40. Scochi CGS, Munari DB, Gelbcke FL, Erdmann AL, Gutiérrez MGR, Rodrigues RAP. The strict sense nursing postgraduation in Brazil: advances and perspectives. Rev Bras Enferm. 2013 Set; 66(Esp):80-9.

41. Rocha PK, Prado ML, Silva DMGV. Convergent care research: use in developing models of nursing care. Rev Bras Enferm. 2012 Nov-Dez; 65(6):1019-25.

42. Carvalho EC, Laus AM, Caliri MHL, Rossi LG. From the production to the use of research results in care practice: a consolidating experience. Rev Bras Enferm. 2010 Set-Out; 63(5):853-8.

43. Pedrosa KKA, Oliveira ICM, Feijão AR, Machado RC. Evidence-based nursing: characteristics of studies in Brazil. Cogitare Enferm. 2015 Out-Dez; 20(4):733-41.

44. Pimenta CAM, Pastana ICASS, Sichieri K, Solha RKT, Souza W. Guia para construção de protocolos assistenciais de enfermagem. São Paulo (SP): COREN; 2015.

45. Vieira AC, Bertoncello KCG, Girondi JB, Nascimento ERP, Hammerschmidt KSA, Zefeino MT. Perception of emergency nurses in using a chest pain assessment protocol. Texto Contexto Enferm [Internet]. 2016 Abr [cited 2016 Oct 31]; 25(1):1-7. Available from: http:// www.scielo.br/scielo.php?script=sci_ arttext\&pid=S0104-07072016000100326\&lng=en\&nr $\mathrm{m}=\mathrm{iso \& t} \operatorname{lng}=\mathrm{pt}$

46. Alexandre NMC, Coluci MZO. Content validity in the development and adaptation processes of measurement instruments. Cienc Saúde Coletiva. 2011 Jul; 16(7):3061-8.

47. Lynn MR. Determination and quantification of content validity. Nurs Res. 1986 Nov-Dez; 35(6):382-5.

48. Pasquali L. Principles of elaboration of psychological scales. Arch Clin Psychiatry. 1998 Set-Out; 25(5):206-13.

49. Agree next steps consortium. The agree II instrument [Internet]. 2009 [cited 2015 Jan 30]. Available from: http://www.agreetrust.org 